\title{
Path Analysis on the Association between Predisposing, Enabling, and Reinforcing Factors, and House Sanitation in Bengkulu, Sumatera
}

\author{
Shinta Nasir'1), Bhisma Murti'), Nunuk Suryani²) \\ 1) Masters Program in Public Health, Universitas Sebelas Maret \\ 2)Faculty of Teaching and Educational Sciences, Universitas Sebelas Maret
}

\begin{abstract}
Background: Poor sanitation is one of the primary causes of communicable disease worldwide. According to UNICEF (2012) 116 million people in Indonesia in 2010 were lacking in standard sanitation. In Bengkulu province, only 33.18\% household in 2014 and $39.22 \%$ in 2015 had access to good sanitation. This coverage was lower than that of the national level at $62.14 \%$. This study aimed investigating the association between predisposing, enabling, and reinforcing factors, and house sanitation in Bengkulu, Sumatera.

Subjects and Method: This was an analytic and observational study with cross sectional design. This study was conducted in Teluk Segara District, Bengkulu, Sumatera from November to December 2016. A total of 120 households were selected by fixed exposure sampling for this study. The dependent variable was household sanitation. The independent variables were family education, family income, health education, social capital, and health behavior. The data were collected by a set of questionnaire and analyzed by path analysis.

Results: Family education $(b=1.08 ; \mathrm{SE}=0.48 ; \mathrm{p}=0.024)$ and health education $(\mathrm{b}=0.19 ; \mathrm{SE}=$ $0.07 ; p=0.007$ ) had positive and statistically significant effect on household sanitation. Health education had positive and statistically significant effect on healthy behavior $(b=0.09 ; \mathrm{SE}=0.04$; $\mathrm{p}=0.018)$. Social capital had positive and marginally significant effect on healthy behavior $(\mathrm{b}=$ 0.05; $\mathrm{SE}=0.03 ; \mathrm{p}=0.099)$. Family income $(\mathrm{b}=0.14 ; \mathrm{SE}=0.45 ; \mathrm{p}=0.756)$ and family education $(b=0.15 ; \mathrm{SE}=0.25 ; \mathrm{p}=0.566)$ did not show significant effect on household sanitation.

Conclusion: Family education and health education had positive and statistically significant effect on household sanitation. Health education had positive and statistically significant effect on healthy behavior. Social capital had positive and marginally significant effect on healthy behavior. Family income and family education did not show significant effect on household sanitation.
\end{abstract}

Keywords: path analysis, predisposing, enabling, reinforcing factors, household sanitation

\section{Correspondence:}

Shinta Nasir. Masters Program in Public Health, Universitas Sebelas Maret. Jl. Ir. Sutami 36A, Surakarta 57126, Central Java. Email: shinta_nasir26@yahoo.co.id.

\section{BACKRGOUND}

Sanitation is an effort to control environmental factors that cause damage or disruption of human development and health in terms of physical, mental and social as well as human survival in the environment. Such control efforts can be carried out through development, provision of sanitation facilities, and infrastructure such as clean water supply, waste water distribution and management, solid waste manage- ment and environmental drainage to protect and improve public health (Afon et al, 2008).

Sanitation problems are one of the health problems that really need to get attention from various parties because they are related to all human activities. Around 780 million people worldwide have no access to drink water and around 2.5 billion lack of a good sanitation (WHO, 2013). Globally, around 2.4 million deaths in the 
Journal of Health Promotion and Behavior (2016), 1(3): 191-200

https://doi.org/10.26911/thejhpb.2016.01.03.06

world (4.2\% of all deaths) could be prevented every year if all people applied clean and healthy life, had clean water facilities, and adequate sanitation.

The Basic Health Research of Indonesia (2010) shows that around 116 million people still do not have adequate sanitation (UNICEF, 2012). Inadequate sanitation was the main cause of the emergence of a disease throughout the world (Bartram and Cairncross, 2010).

Bengkulu was one of the provinces in Indonesia that had access to household sanitation which is still low in 2014 by 33 . $18 \%$ and in 2015 it increased by $39.22 \%$. However, this percentage is still below the percentage of national level household sanitation access, which is equal to $62.14 \%$ (Ministry of Health of Republic of Indonesia, 2016).

Sanitation is one sector that is closely related to poverty, education level, population density, slums, and environmental health problems (Kutai Timur Sanitation Working Group, 2015).

Urban slums, inadequate sanitation, poor hygiene practices, excessive population density, and contaminated water can create unhealthy conditions (UNICEF, 2012). Healthy conditions can be achieved by changing unhealthy behavior into healthy behavior and creating a healthy environment in the household so that health can be maintained and improved by every member of the household and all parties (Ministry of Health, 2007).

According to Lawrence $\mathrm{W}$ Green (1991), the health of a person or society is influenced by behavioral factors. Such behavior is formed from three factors, namely predisposing factors, enabling factors and reinforcing factors (driving factors (Siswantoro, 2012).

Education level is one of the predisposing factors that can affect the condition of environmental sanitation, especially home sanitation. Family income is one of the enabling factors in addition to health facilities and infrastructure, especially home sanitation facilities (clean water, healthy latrines, landfills, and waste disposal sites) (Finny et al, 2013; Wea et al, 2011). Reinforcing factors are factors that encourage behavior, such as health education and social capital.

Poor environmental sanitation in Bengkulu is still an important health problem to overcome. The area of Teluk Segara district in Bengkulu is an area that has a problem with a poor environmental sanitation. Sanitation issues in Teluk Segara district are the most important things to overcome, especially on household sanitation because inside the Segara Teluk District there is a tourist area of Bengkulu that should have a good environmental sanitation so that it can support tourist attraction.

Most of the conditions in the Teluk Segara district area had environmental drainage which still contains trash that were dumped carelessly by the community, there were still many puddles in the drainage around the community's houses. In addition, the distance between houses was still very tight, so there were difficulties in finding land to build waste disposal sites such as septic tanks. People who live in the surrounding environment did not have clean and healthy behaviors such as habit of littering. Some residents who live on the coast used the beach as a sanitation facility so that it polluted the beach. Bengkulu government had made efforts to improve environmental quality such as waste water management, overcoming waste problems in Bengkulu, but these efforts had not been able to work properly because the community had not fully contributed to achieving a successful improvement in environmental quality Bengkulu. 
Based on the background above, the researcher was interested in conducting a study on "Path Analysis on the Association Between Predisposing, Enabling, and Reinforcing Factors, and House Sanitation in Bengkulu, Sumatera ".

\section{SUBJECTS AND METHOD}

$\overline{\text { The study design used was an observational }}$ analytic study with a case control approach. This study was carried out in Bengkulu by taking a location in Teluk Segara district. The independent variables were family education, family income, social capital, and health behavior. While the dependent variable was household sanitation. The sampling technique used was fixed exposure sampling, with a ratio of 2: 1 for case and control subjects, a number of 120 subjects of the heads of the family. The data Table 1. Sample Characteristics

\begin{tabular}{lcc}
\hline \multicolumn{1}{c}{ Characteristics } & Frequency & Percentage (\%) \\
\hline Age of Head of the family & 17 & 14.2 \\
Not productive & 103 & 85.8 \\
$\begin{array}{l}\text { Productive } \\
\text { The job of head of the family }\end{array}$ & 22 & 18.3 \\
Fisherman & 22 & 18.3 \\
Daily Workers & 17 & 14.2 \\
Private employees & 38 & 31.7 \\
Entrepreneur / Trader & 21 & 17.5 \\
Civil servants & & 36.7 \\
Head of the family Education & 44 & 63.3 \\
Low education & 76 & \\
High education & & \\
\hline
\end{tabular}

\section{Univariate Analysis}

Table 2 shows that from 120 subjects of the study, most of the heads of the family had poor home sanitation (66.7\%) and few of heads of the family had good home sanitation (33.3\%). Most heads of the family have a higher education level (63.3\%) and few of head of the family $s$ had a low education level (36.7\%). Most families had high income, namely $\geq 2,300,000$ rupiah per month (50.8\%) and a few families had low income which was $<2,300,000$ rupiah collection tools used were questionnaires and observation sheets (checklist). The data analysis used in this study was path analysis, carried out using the AMOS 22 SPSS program.

\section{RESULTS \\ 1. Sample Characteristics}

Table 1 shows that of the 120 subjects of the study it was found that most of the heads of families were in productive age (85.8\%) and a small number of head of family were in unproductive age (14.2\%). Most heads of the family worked as entrepreneur/ trader (31.7\%) and a small number of heads of the family worked as civil servants (17.5\%). Most heads of the family were highly educated (63. 3\%) and a small number of heads of the family were low educated (36.7\%). per month (49.2\%). Most families had received health counseling (58.3\%) and a small number of families had never received health education (41.7\%). Most families had high social capital in the community (58.3\%) and few families have low social capital in the community (41.7\%). Most families had good clean and healthy behavior (75.8\%) and a small number of families have a clean and poor healthy life behavior (24.2\%). 
Journal of Health Promotion and Behavior (2016), 1(3): 191-200

https://doi.org/10.26911/thejhpb.2016.01.03.06

Table 2. The Description of the Variable of the Study

\begin{tabular}{lcc}
\hline \multicolumn{1}{c}{ Independent Variables } & n & \% \\
\hline Home Sanitation & & \\
Bad & 80 & 66.7 \\
Good & 40 & 33.3 \\
Family Education & & 36.7 \\
Low education & 44 & 63.3 \\
Higher education & 76 & 49.2 \\
Family Income & & 50.8 \\
Low income (<2.300.000) & 59 & 41.7 \\
High Income ( $\geq 2.300 .000)$ & 61 & 58.3 \\
Health Counseling & & 41.7 \\
Not yet & 50 & 58.3 \\
Already & 70 & 24.2 \\
Locial Capital Social Capital & & 75.8 \\
High Social Capital & 50 & \\
Health Behavior & 70 & \\
Bad & & \\
Good & 29 & \\
\hline
\end{tabular}

\section{Bivariate Analysis}

Table 3 below presents the results of the correlation test of Pearson product moment about the association between health education and clean and health behavior, $r$ value was 0.28 with a $p$ value of 0.002 . This shows that there was a weak and statistically significant association between health education and clean and healthy lifestyle. Correlation test of Pearson resulted the association of social capital with clean and healthy behavior $(\mathrm{r}=0.22 ; \mathrm{p}=0.016)$. It showed that there was a weak and statistically significant association between social capital and health behavior.

Tabel 3. Correlation test of Pearson product moment among health education, social capital and clean and health behavior

\begin{tabular}{lcc}
\hline Variable & $\mathbf{r}$ & $\mathbf{p}$ \\
\hline Health Counseling & 0.28 & 0.002 \\
Social Capital & 0.22 & 0.016 \\
\hline
\end{tabular}

Table 4 present the results of correlation test of the Pearson product moment about the association between health behavior with household sanitation, the $r$ value was
0.37 with a $\mathrm{p}<0.001$. This showed that there was a weak and statistically significant association between health behavior and household sanitation.

Table 4. Correlation test of Pearson product moment between health behavior, health education, social capital, family education and household sanitation

\begin{tabular}{lcc}
\hline Variable & $\mathbf{r}$ & $\mathbf{p}$ \\
\hline Health Behavior & 0.37 & $<0.001$ \\
Health Counseling & 0.35 & $<0.001$ \\
Social Capital & 0.22 & 0.017 \\
Family Education & 0.26 & 0.004 \\
\hline
\end{tabular}

There was a positive association between health education and household sanitation $(\mathrm{r}=0.35 ; \mathrm{p}<0.001)$. This showed that there was a weak and statistically significant association between health education and household sanitation.

There was a positive association between social capital and household sanitation $(\mathrm{r}=0.22 ; \mathrm{p}=0.017)$. This showed that there was a weak and statistically significant association between social capital and household sanitation. 
There was a positive association between family education and home sanitation ( $\mathrm{r}=0.26 ; \mathrm{p}=0.004)$. This showed that there was a weak and statistically significant association between family education and household sanitation.

\section{Path Analysis}

From Figure 1 the values of the association between each variable were obtained from both exogenous and endogenous variables.



Figure 1. Structural models of the Variables measured for household sanitation

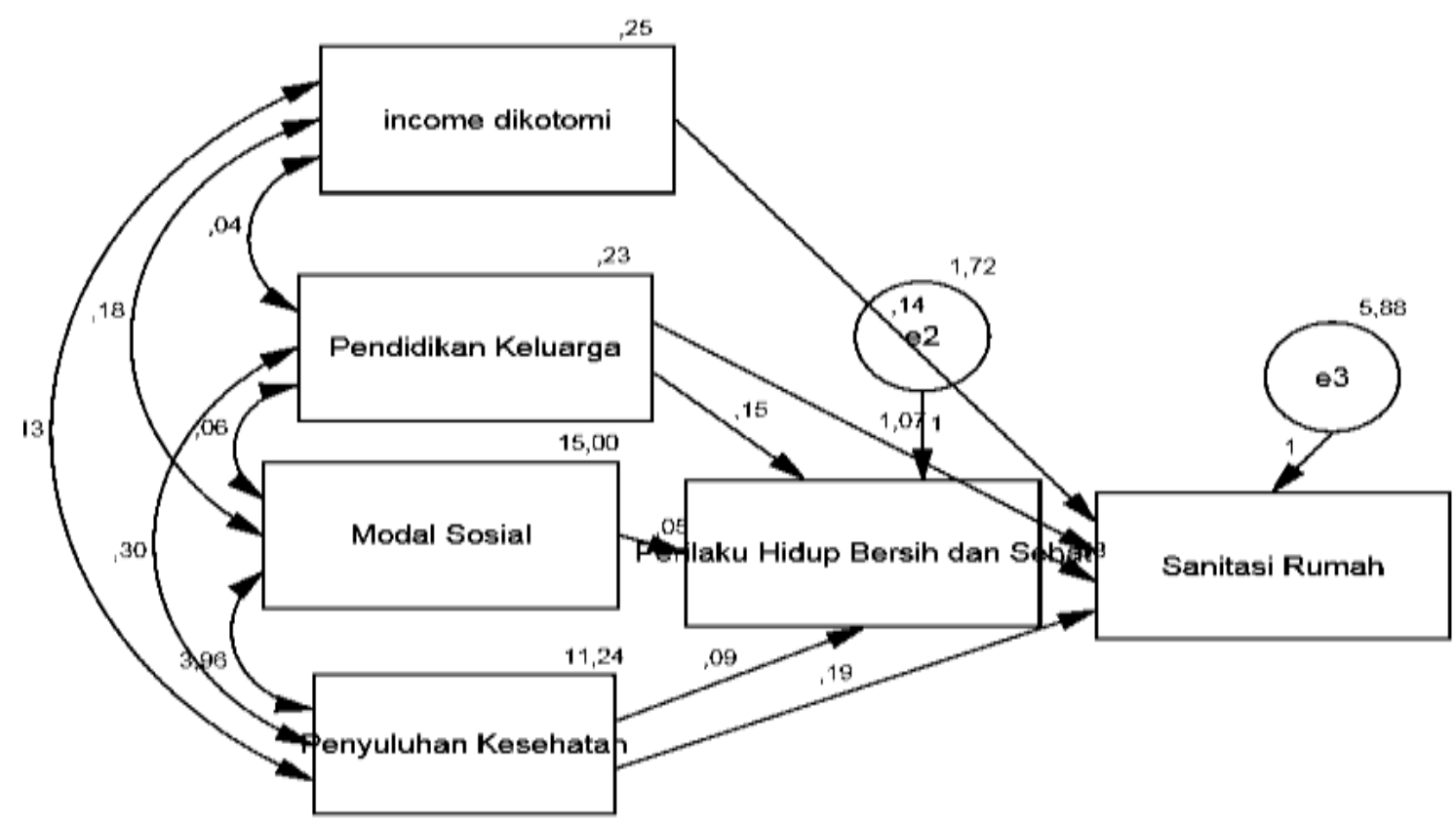

Figure 2. Structural models with standardized solutions 
Journal of Health Promotion and Behavior (2016), 1(3): 191-200

https://doi.org/10.26911/thejhpb.2016.01.03.06

Figure 2 shows the structural model after estimation using IBM SPSS AMOS 22, so that the value obtained as in the Figure 2. Indicators that showed the suitability of the path analysis model, as shown in table 5, also indicates the existence of a goodness of fit measure that the CMIN fit index was 1.01 with a value of $\mathrm{p}=0.603>0.05 ; \mathrm{NFI}=$ $0.99>0.90$; CFI $=1.00>0.90 ;$ RMSEA $=$ $<0.001$ which meant that the empirical model met the criteria specified and stated in accordance with empirical data.

Table 5. Results of Path Analysis of Factors Relating to Household Sanitation

\begin{tabular}{lllllll}
\hline \multicolumn{1}{c}{$\begin{array}{c}\text { Dependent } \\
\text { Variable }\end{array}$} & & \multicolumn{1}{c}{$\begin{array}{c}\text { Independent } \\
\text { Variable }\end{array}$} & $\mathbf{b}^{*}$ & $\mathbf{S E}$ & $\mathbf{p}$ & $\boldsymbol{\beta}^{* *}$ \\
\hline $\begin{array}{l}\text { Direct Association } \\
\text { Household sanitation }\end{array}$ & $\leftarrow$ & Healthy behavior & 0.58 & 0.17 & $<0.001$ & 0.29 \\
& $\leftarrow$ & Counseling & 0.19 & 0.07 & 0.007 & 0.23 \\
& $\leftarrow$ & Education & 1.08 & 0.48 & 0.024 & 0.19 \\
Indirect Association & $\leftarrow$ & Family income & 0.14 & 0.45 & 0.756 & 0.03 \\
Healthy behavior & $\leftarrow$ & Counseling & & & & \\
& $\leftarrow$ & Social Capital & 0.09 & 0.04 & 0.018 & 0.22 \\
& $\leftarrow$ & Education & 0.05 & 0.03 & 0.099 & 0.15 \\
& & & 0.15 & 0.25 & 0.566 & 0.05
\end{tabular}

N Observation $=120$

Fit Model

CMIN $=1.01 \mathrm{p}=0.603(\geq 0.05)$

NFI $\quad=0.99$

CFI $=1.00$

RMSEA $=<0.001$

* $\mathrm{b}=$ unstandardized path coefficient

** $\beta=$ standardized path coefficient

Table 5 shows the results of path analysis. Table 5 showed that household sanitation was directly and positively associated with health behavior $(b=0.58$, $\mathrm{SE}=0.17, \mathrm{p}<0.001)$, health counseling $(\mathrm{b}=$ 1.08, $\mathrm{SE}=0.07, \mathrm{p}=0.007$ ), health education $(\mathrm{b}=1.08, \mathrm{SE}=0.48, \mathrm{p}=0.024)$, and family income $(b=0.14, \mathrm{SE}=0.45, \mathrm{p}=0.756)$.

Table 5 showed that household sanitation was indirectly and positively associated with counselling $(b=0.09, \mathrm{SE}=$ 0.04, $\mathrm{p}=0.018)$, social capital $(b=0.05$, $\mathrm{SE}=0.03, \mathrm{p}=0.099$ ), and family education $(b=0.15, S E=0.25, p=0.566)$ trough healthy behavior.

\section{DISCUSSION}

\section{Association between family educa- tion and household sanitation}

The results of path analysis in this study indicates that there is a positive association between family education and household sanitation both directly and indirectly. The association between family education and household sanitation is indirectly related to health behavior. The head of the family who has a higher education would have a cleaner and healthier lifestyle and more willing to have good household sanitation. The education level of the head of the family had an important role in family health. With the existence of higher education owned by the head of the family, it was expected that they would be able to receive and understand information, especially information about health issues so that they could improve family health status. Education is a factor forming of health behavior, but in the theory stated by Blum in Roni et al (2013), behavior could also be influenced by other factors such as social, cultural, economic and political. 
The results of this study are in line with the study conducted by Ambarwati (2013), Irawati and Wahyuni (2011), which explained that there was a positive association between the level of education of the head of the family and health behavior. In addition, the results of the study showed that there was a direct association between the education of the head of the family and household sanitation. The results of these studies are consistent with the study conducted by Rahmah (2015), which showed that there was an association between education and healthy houses.

\section{The association between family income and household sanitation}

The results of the path analysis in this study indicated that family income had a direct and positive association with home sanitation, but it was not statistically significant. This is in line with the study conducted by Hardjono (2003) which showed that there was an insignificant association between family income and clean water management practices in housewives who had toddlers. This was possible because income obtained by the family was not enough to meet their daily needs. The results of the observations in the study also showed that families with high income in clean water management still used simple equipment for the purposes of clean water management, such as using barrels, drums, and so on as water storage.

In addition, the insignificant association between family income and household sanitation could also caused by other factors, namely social, cultural, behavioral, and so on. A study conducted by Routray et al. (2015) showed that there was an association between socio-cultural and behavioral factors with the availability of latrine sanitation facilities in Odisha rural areas.

However, the results of the path analysis in this study indicated that there was a direct and positive association between family income and household sanitation. It was supported by a study conducted by Zainiyah et al. (2013), which showed that there was a positive association between the economic level and latrine ownership family. The economic level of a family was closely related to the ownership of family latrines. High family income increased the possibility of the family to have a healthy latrine, on the contrary low income reduced the possibility of the family to have healthy latrines.

\section{The association between social capital and household sanitation}

The results of the path analysis in this study indicated that there was a positive association between social capital and household sanitation, but indirectly through health behavior. The norms and values that are formed in social capital can affect a person's health behavior. With the existence of norms that had been made in the community, it was expected that one can have a better behavior. After the norm was formed it was expected that no more people would have the habit of defecating on the beach or in other places.

The results of this study are in line with study conducted by Bisung et al (2014), which showed that there was an influence of social capital in the form of community participation in handling sanitation problems, especially in handling clean water facilities.

A study conducted by Isunju et al. (2011) also showed that rural people who lived without social networks had poor kinship relationships. This resulted in a lack of sense of responsibility of the population in maintaining sanitation in their neighborhoods which and cause damage to public sanitation facilities provided by the government. 
Journal of Health Promotion and Behavior (2016), 1(3): 191-200

https://doi.org/10.26911/thejhpb.2016.01.03.06

This is also supported by the theory of Putnam (2000), which explained that the concept of social capital put emphasis on community togetherness to achieve the goal of improving the quality of life. Some values and elements references which were the spirit of social capital were participatory attitudes, caring attitudes, mutual giving and receiving, mutual trust, and strengthened by the values and norms that support it.

It can be concluded that community participation in handling sanitation issues, especially sanitation facilities in the community's home environment is very important. If community participation is high, it is possible that the condition of home sanitation and the environment will be better.

\section{The association between health education and household sanita- tion}

The results of the path analysis in this study indicated that there was a positive association between health education and household sanitation both directly and indirectly. The association between health education and household sanitation indirectly affects the health behavior. Based on the results of the study, the health counseling obtained by family members was mostly obtained through electronic media such as television than from mass media and outdoor media such as billboards, banners, and others because of the limited supply of media or information in the community. While health counseling delivered by health workers was obtained by family members when attending health counseling at the Community Health Center, as well as in the district office. Health education delivered were the provision of clean water facilities, provision of healthy latrines, garbage disposal, and disposal of wastewater.
The results of this study are supported by study conducted by Tumiwa et al. (2015), which showed that there was a meaningful association between health education and health behavior. Health education that was delivered well, easy to understand, non-monotonous and delivered briefly, densely and clearly by health workers had 15 times greater chance for the community to implement health behavior compared to the community or household that had inadequate facilities of sanitation.

\section{The association between health behavior and household sanitation} Health behavior is a set of behaviors that are practiced on the basis of awareness as a result of learning that makes a person or family can help themselves to improve their health status and play an active role in realizing the health of their community (Mubarak, 2012), in this case health behavior regarding the use of adequate household sanitation facilities.

The results of the path analysis in this study indicate that there was a positive association between health behavior and household sanitation. Families who have clean and healthy living behaviors will be able to improve the condition of household sanitation. Someone who has good behavior towards in using home sanitation facilities will improve their health status.

The results of this study are in line with a study conducted by Darsana et al. (2014) which showed that there was an association between the habits of people who defecate carelessly and the ownership of family latrines. The results of other study was conducted by Istiqomah (2015) which showed that residents who did not have clean and healthy behavior such as the habit of littering the river, garden, and yard due to lacking of sanitation facilities such as landfills. Household solid waste piled at the bottom of the river will make the river more 
shallow and can cause flooding. In addition, waste dumped carelessly in the yard can cause the environment to become slums and become a vector habitat for diseases, especially environment-based diseases such as diarrhea, dengue fever, and acute respiratory infection. These diseases will increase if the community does not behave clean and healthy.

There was a direct and positive association between family education, family income, social capital, health education, health behavior and household sanitation. There was an indirect and positive association between family education, social capital, health education and household sanitation through health behavior.

\section{REFERENCE}

Afon AO, Okanlawon SA, Adigun FO, Odunola OO (2008). Evolving Sustainable Environmental Sanitation Behaviour Among Secondary School Students: Home and School as Correlated in Ogbomoso Nigeria. WIT Transactions on Ecology and the Enviroment, 117 (10): 615-625.

Ambarwati ER (2013). Pendidikan, Pendapatan Kepala Keluarga dengan Perilaku Hidup Bersih dan Sehat. Jurnal Ilmu Kebidanan, 1 (1): 45-51.

Bartram J, Caimcross (2010). Hygiene, Sanitation, and Water: Forgotten Foundations of Health. Plos Medicine. 7 (11): 1-9.

Bisung E, Elliott SJ, Wallace CJS, Karanja DM, Bernard A (2014). Social Capital, Collective Action and Access to Water in Rural Kenya. Social Science and Medicine, 119: 147-154.

Darsana IN, Mahayana IMB, Patra IM (2014). Faktor-faktor yang berhubungan dengan kepemilikan jamban keluarga di Desa Jehem Kecamatan Tembuku Kabupaten Bangli Tahun
2012. Jurnal Kesehatan Lingkungan, 4(2): 124-133.

Departemen Kesehatan RI (2007). Buku Paket Pelatihan Kader Kesehatan dan Tokoh Masyarakat dalam Pengembangan Desa Siaga. Jakarta: Direktorat Jenderal PPM-PLP.

Finny FT, Rattu AJM, Tucunan AAT (2013). Hubungan antara faktor predisposing, enabling, dan reinforcing dengan perilaku hidup bersih dan sehat tatanan rumah tangga di Kecamatan Remboken Kabupaten Minahasa. Paradigma Sehat, 3(2): 1-11.

Hardjono Y (2003). Praktik pengelolaan air bersih oleh ibu rumah tangga yang mempunyai balita dan faktor-faktor yang berhubungan di Desa Wringin Putih Kecamatan Bergas Kabupaten Semarang Tahun 2003. Tesis, Program Pascasarjana Universitas Diponegoro Semarang.

Irawati E, Wahyuni (2011). Gambaran karakteristik keluarga tentang perilaku hidup bersih dan sehat (PHBS) pada tatanan rumah tangga di Desa Karangasem Wilayah Kerja Puskesmas Tanon II Sragen. Gaster, 8(2): 741-749.

Istiqomah N (2015). Potret perilaku hidup bersih dan sehat masyarakat Pakumbulan Buaran Kabupaten Pekalongan. Jurnal Pena Medika, 5 (1): 103-109.

Isunju JB, Schwartz K, Schouten MA, Johnson WP, Van Dijk MP (2011). Socioeconomic aspects of improved sanitation in slums: A review. Public Health 125: 368-376.

Kementerian Kesehatan RI (2016). Profil Kesehatan Indonesia 2015. Jakarta: Pusat Data dan Informasi Kementerian Kesehatan RI 2016.

Mubarak WI (2012). Ilmu kesehatan masyarakat: Konsep dan aplikasi dalam kebidanan. Jakarta: Salemba Medika. 
Journal of Health Promotion and Behavior (2016), 1(3): 191-200

https://doi.org/10.26911/thejhpb.2016.01.03.06

Pokja Sanitasi Kutai Timur (2015). Pemutakhiran Strategi Sanitasi Kabupaten Kutai 2015-2019.

Putnam R (2000). Bowling Alone: The Collapse and Revival of America Community. New York; Social Capital; Civic Community. Organization and Education.

Rahmah UDMN (2015). Hubungan karakteristik kepala keluarga dengan rumah sehat di Desa Duwet Kecamatan Baki Kabupaten Sukoharjo. Artikel Publikasi Ilmiah, Program Studi Kesehatan Masyarakat Fakultas Ilmu Kesehatan Universitas Muhammadiyah Surakarta.

Roni TS, Ruhmawati T, Sukandar D (2013). Hubungan Pendidikan dan Penghasilan dengan Perilaku Hidup Bersih dan Sehat. Jurnal Kesehatan Lingkungan Indonesia, 12 (1): 22-25.

Routray P, Schmidt WP, Boisson S, Clasen T, Jenkins MW (2015). Socio-cultural and behavioral factors constraining latrine adoption in rural coastal Odisha: an exploratory qualitative study. BMC Public Health 15:880.

Siswantoro T (2012). Analisis pengaruh predisposing, enabling, dan reinforcing factors terhadap kepatuhan pengobatan TB paru di Kabupaten
Bojonegoro. Jurnal Administrasi Kebijakan Kesehatan, 10 (3): 152-159.

Tumiwa FF, Rattu AJM, Tucunan AAT (2015). Hubungan Antara Faktor Predisposing, Enabling, dan Reinforcing dengan Perilaku Hidup Bersih dan Sehat Tatanan Rumah Tangga di Kecamatan Remboken Kabupaten Minahasa. [internet]. http://jkesmasfkm. unsrat.ac.id.

UNICEF (2012). Ringkasan kajian air bersih, sanitasi, dan kebersihan. Indonesia: UNICEF.

Wea MFY, Romeo P, Limbu R (2011). Hubungan Antara Faktor Predisposisi dan Faktor Pemungkin dengan Praktek Penggunaan Jamban pada Masyarakat Pesisir Pantai Kelurahan Oesapa. MKM, 6 (1): 15-20.

WHO. (2013). Sanitation as a Key to Global Health. Voices from the Field. United Nations University, Institute for Water, Enviroment and Health.

Zainiyah AN, Mardoyo S, Marlik. (2013). Hubungan kepemilikan jamban dengan tingkat pengetahuan dan pendidikan masyarakat (Studi di Desa Mendalan Kecamatan Winongan Kabupaten Pasuruan Tahun 2012). Gema Kesehatan Lingkungan, 10(1): 5054 . 